\title{
Nutritional response and clinical complications in patients with post-pyloric and gastric enteral tubes
}

\author{
Resposta nutricional e complicações \\ clinicas em pacientes com uso de \\ sonda gástrica ou pós-pilórica
}

\author{
Leandro Augusto Kuhl OPSFELDER ${ }^{1}$ (ID) 0000-0001-7687-0182 \\ Guilherme Welter WENDT ${ }^{2}$ ID 0000-0002-9014-6120 \\ Danilo Rodrigues Pereira da SILVA ${ }^{3}$ ID 0000-0003-3995-4795 \\ Marina Daros MASSAROLLO4 ID 0000-0003-1136-3328 \\ Lirane Elize Defante FERRETO 5 (ID) 0000-0002-0757-3659 \\ Ana Paula VIEIRA5 (iD) 0000-0003-2743-4813
}

\section{A B S T R ACT}

\section{Objective}

The present study assessed the differences in nutritional markers (albumin, transferrin, total body fat, and body mass index) and clinical complications (diarrhea, vomiting, and diet interruptions) associated with enteral nutrition.

\section{Methods}

This is an open-label, randomized, two-arm parallel-group controlled clinical trial. Out of 105 patients assessed for eligibility, 35 adult patients were randomly divided into two groups and followed for 28 days. The sample comprised a

\footnotetext{
1 Hospital São Francisco, Unidade de Terapia Intensiva. Francisco Beltrão, PR, Brasil.

2 Universidade Estadual do Oeste do Paraná, Centro de Ciências da Saúde, Curso de Medicina. Francisco Beltrão, PR, Brasil.

3 Universidade Federal de Sergipe, Curso de Educação Física, Departamento de Educação Física. São Cristóvão, SE, Brasil.

4 Universidade Estadual do Oeste do Paraná, Centro de Ciências da Saúde, Curso de Nutrição. Francisco Beltrão, PR, Brasil.

5 Universidade Estadual do Oeste do Paraná, Centro de Ciências da Saúde, Programa de Pós-Graduação Stricto Sensu em Ciências Aplicadas à Saúde. Rod. Vitório Traiano, Km 2, Secretaria do Curso de Medicina, Bairro Água Branca, 85601-970, Francisco Beltrão, PR, Brasil. Correspondence to: AP VIEIRA. E-mail: <anap.encruz@gmail.com>.

Article elaborated from the dissertation by L OPSFELDER, entitled "Estudo clínico randomizado do uso da sonda enteral pós-pilórica versus gástrica em pacientes hospitalizados”. Universidade Estadual do Oeste do Paraná; 2019.
}

How to cite this article

Opsfelder LAK, Wendt GW, Silva DRP, Massarollo MD, Ferreto LED, Vieira AP. Nutritional response and clinical complications in patients with post-pyloric and gastric enteral tubes. Rev Nutr. 2021;34:e200283. https://doi.org/10.1590/1678-9865202032e200283 
heterogeneous group of severely ill individuals initially treated in the intensive care units. Neurological conditions (i.e., strokes and brain tumours) were the most common reasons for hospitalization. Patients had one singularity: the clinical need for exclusive enteral nutrition therapy. One group received the diet via gastric tube and the other via a post-pyloric tube.

\section{Results}

The groups presented increases in the calories prescribed and administered, as well as reduced diet discontinuation. Although similar values were observed up to day 21, the post-pyloric group showed increased albumin levels compared to the gastric group on Day 28. Transferrin levels increased over time in both groups.

\section{Conclusion}

There were no differences in the complications recorded between groups, albeit serum albumin significantly increased in the post-pyloric group.

Keywords: Clinical trial. Enteral nutrition. Feeding methods. Gastrointestinal intubation. Intensive care units. Nutritional support.

\section{R E S U M O}

\section{Objetivo}

Avaliar diferenças tanto nos marcadores nutricionais (albumina, transferrina, gordura corporal e índice de massa corporal) quanto nas complicações clínicas (diarreia, vômitos e interrupções na dieta) associadas à nutrição enteral administrada através de duas vias tradicionais.

\section{Métodos}

Este é um ensaio clínico de tratamento, paralelo de dois braços, aberto e randomizado controlado. Dos 105 participantes avaliados para elegibilidade, 35 pacientes adultos foram divididos aleatoriamente em dois grupos e seguidos por 28 dias. A amostra foi formada por um grupo heterogêneo e gravemente enfermo, tratados inicialmente em unidades de terapia intensiva. Condições neurológicas, como acidente vascular e tumores cerebrais foram as razões principais para hospitalização. Os pacientes tinham em comum um aspecto, a saber, a necessidade clínica exclusiva de receber nutrição enteral. Um grupo recebeu a dieta via sonda gástrica e o outro através de sonda pós-pilórica.

\section{Resultados}

Os grupos apresentaram aumento de calorias prescritas e administradas, bem como redução da descontinuação da dieta. Embora valores semelhantes tenham sido observados até o $21^{\circ}$ dia, o grupo pós-pilórico apresentou aumento dos níveis de albumina em relação ao grupo gástrico no dia 28. Os níveis de transferrina aumentaram ao longo do tempo em ambos os grupos.

\section{Conclusão}

Não houve diferenças nas complicações registradas entre os grupos, embora níveis séricos de albumina aumentaram significativamente no grupo pós-pilórico.

Palavras-chave: Ensaio clínico. Nutrição enteral. Técnicas de Alimentação. Intubação grastrointestinal. Unidades de terapia intensiva. Suporte Nutricional.

\section{NTRODUCT IO N}

Considering the specific needs for adequate nutrition in hospitalized patients, a diverse set of techniques are used for administrating nutritional diets in various clinical situations. Patients with difficulties in obtaining adequate oral nutrition are often subject to gastrointestinal tubes. Data from several institutions shows marked nutritional depletion, which impacts almost $50 \%$ of hospitalized patients $[1,2]$. Indeed, malnutrition affects between $40 \%-60 \%$ of admitted patients in Latin America, resulting in a $61 \%$ increase in the hospitalization costs when compared to well-nourished patients [3]. 
An aggravating factor is the improper diagnosis of malnutrition, which may well worsen during hospitalization [4,5]. Disease-associated malnutrition is characterized by the insufficient intake, use, or absorption of nutrients/energy, and it is affected by factors such as age, functional disability, and comorbidities, thus leading to rapid weight loss and organic dysfunction [6]. For these reasons, hospitalized patients receive special attention by multidisciplinary nutritional therapy teams $[7,8]$. After concluding the nutritional assessment, plans and adaptations must envision the patient's best care until discharge [9]. In some circumstances, Enteral Nutrition Therapy (ENT) is required when patients cannot or should not eat orally, or when the oral intake is insufficient. ENT consists in administering nutrients through the gastrointestinal tract using a tube, probes, or ostomies located in the digestive tract. ENT should be the first option of treatment for patients with nutritional risk or those already malnourished [10-12].

Despite the great need for the use of enteral diets in Brazil and their regulations, there is no data that accurately describes the estimates of ENT application in hospitalized patients [13]. Moreover, there is no consensus about the best position for the enteral tube when administrating these diets, which often require rapid clinical judgment or are based in the availability of resources at institutions [14]. For instance, both the American Society for Enteral Nutrition and the European Society for Clinical Nutrition and Metabolism recommend the post-pyloric route for patients with risk for pneumonia. However, the post-pyloric enteral tube requires some expertise, and is thus associated with delays in starting ENT $[15,16]$.

For intensive care health professionals, malnutrition must be tackled accordingly to avoid further complications and evidence is needed to support doctors' decisions when administering ENT $[12,17]$. Consequently, the present study aims to assess the differences in both nutritional markers (albumin, transferrin, total body fat, and body mass index) and clinical complications (diarrhea, vomiting, and diet interruptions) associated with ENT administered via the two traditional routes already described. Our investigation builds upon past international research and differs from previous national studies as several clinical and nutritional outcomes were assessed at different time points in adults admitted to Intensive Care Units (ICU).

\section{METHODS}

This is an open-label, randomized, two-arm parallel-group controlled clinical trial. Out of the 105 participants assessed for eligibility, 35 patients were selected, randomly divided into two groups and followed for 28 days (Figure 1). The sample comprised a heterogeneous group in terms of age, sex, and socioeconomic status. Most of these patients were seriously ill and started treatment in the intensive care units. Neurological conditions (i.e., strokes and brain tumours) were the most common reasons for hospitalization. Nonetheless, patients had one singularity: the clinical need for exclusive enteral nutrition therapy. Patients were excluded when transferred to other hospitals or when another route of diet provision was suggested. One group received the diet via gastric tube $(n=17)$ and the other via a post-pyloric tube $(n=18)$. As a method of randomization, patients were allocated in one of the groups according to chronological, not clinical, order - i.e., odd numbers received ENT in the postpyloric group and even numbers were allocated in the gastric group. Patients were in treatment at a Hospital in the municipality of Francisco Beltrão (PR), and the study was approved by a Research Ethics Committee (Western Paraná State University, approval number 2.311465) and registered as a clinical trial (RBR-6TNM7D) at the Registro Brasileiro de Ensaios Clínicos (Brazilian Record of Clinical Trials). Consent forms were obtained from all participants. 


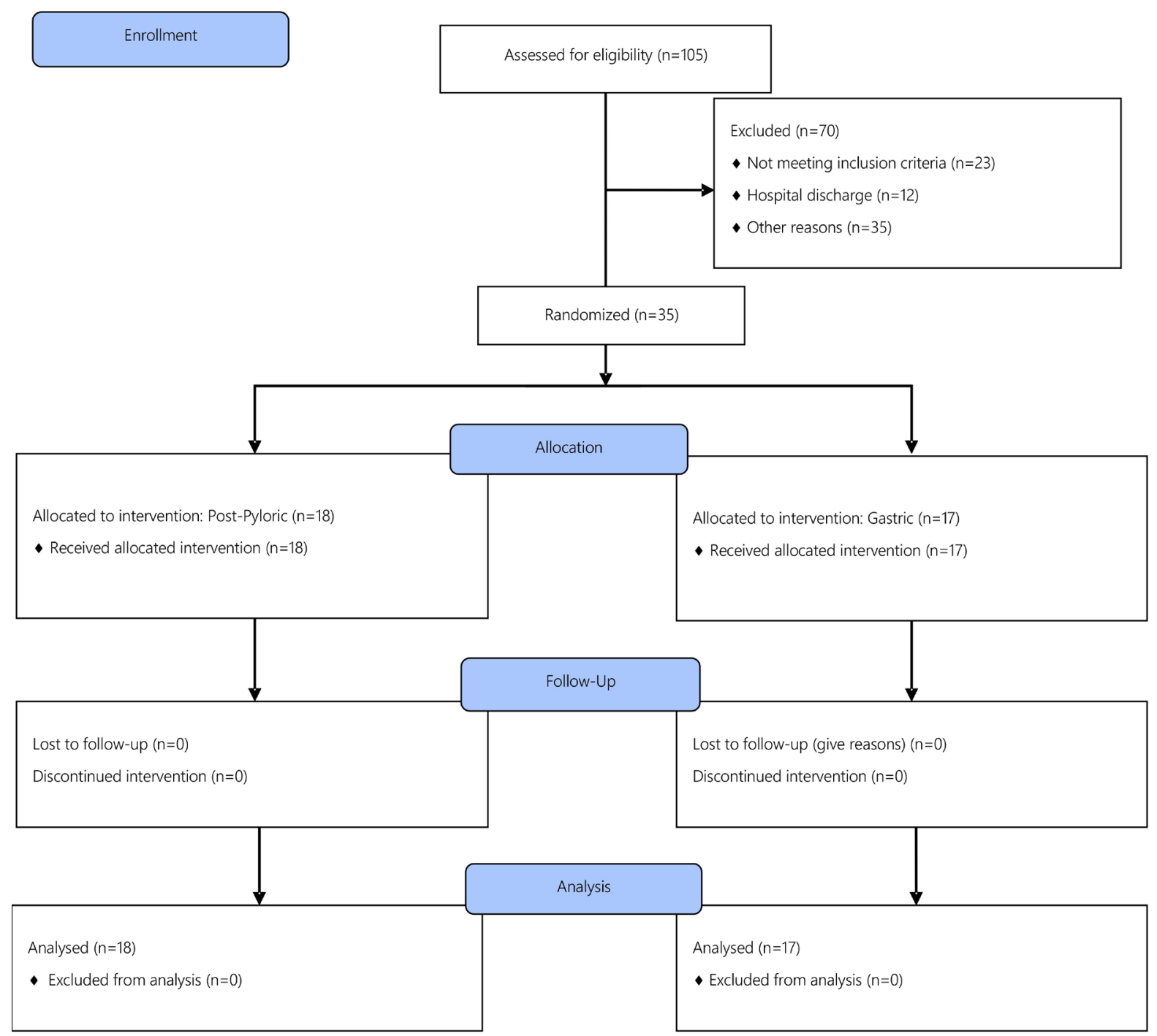

Figure 1 - Consort flow diagram.

At the time of hospital admission, data on gender, age, weight, height, diagnosis, and Body Mass Index (BMI) were considered for the diet planning. Diets for the post-pyloric and gastric groups resulted on an average of $1275,7 \pm 252,5 \mathrm{kcal} /$ day and $1346,2 \pm 296,3 \mathrm{kcal} /$ day, respectively. The volumes of both prescribed and administered diets were recorded daily. Serum glycemia was taken into consideration when selecting diets. Jevity hical $1.5 \mathrm{kcal} / \mathrm{mL}$ was used for non-diabetic patients, while Glucerna $1.0 \mathrm{kcal} / \mathrm{mL}$ was prescribed for those with confirmed diagnosis of diabetes mellitus or for those with two consecutive hyperglycemic tests performed six hours apart (blood glucose $\geq 180 \mathrm{mg} / \mathrm{dL}$ ). Both formulations contained $17 \%$ protein ( $100 \%$ of those from calcium and sodium caseinate [Glucerna], and $72 \%$ of sodium caseinate, $17 \%$ of soy protein isolate, and $11 \%$ of calcium caseinate [Jevity hical]).

The placement of the tubes followed the protocol from the institution's nutritional therapy multidisciplinary team. In summary, the head of the bed was raised to a $45^{\circ}$ Fowler's position. The head was moved to the right lateral decubitus. Measurements and markings of the distancing between the earlobe and the xiphoid appendix, and between the tip of the nose and the base of the xiphoid appendix were 
performed, adding additional 15 to $30 \mathrm{~cm}$. Water was then injected into the probe and the physician was asked to use prokinetic agents [18]. The probe was inserted into one of the nostrils until the desirable position. Signs of cyanosis, dyspnoea, and cough were observed. The positions of the tubes were confirmed by X-rays and examinations by the physicians. Diets were then administered by a closed system through continuous pump infusion; velocity started with $21 \mathrm{~mL}$ per hour, progressing according to patients' acceptance and protocol standards [19]. The Dobbhoff 12 enteral probe was used for both groups.

Serum albumin and transferrin were collected by the nursing team every week. Anthropometric data were provided by tetra-polar electrical bioimpedance, using body fat percentage and $\mathrm{BMI}$ as markers. Electrical bioimpedance was used to estimate the lean mass, fat mass, BMI, basal metabolic rates, and total body water; electrodes were placed in established locations [20]. As some patients had body edema, five measurements of body fat percentage were taken. The complications recorded were diarrhea (e.g., three or more liquid or semi-liquid evacuations in a 24-hour period), vomiting/abdominal distension, and diet interruptions (determined according to the institution's protocol and implemented by the on-call nurse with the agreement of the on-call physician). These data were collected at the time of admission, on the seventh day, on the fourteenth day, on the twenty-first day, and on the twenty-eighth day.

Measures of central tendency and dispersion were used for descriptive purposes. The data distribution was tested using the Shapiro-Wilk test. Thus, variables that were normally distributed were analysed with parametric tests. When the assumption of normality was not met, nonparametric tests or logarithmic adjustments were used. To compare patients' baseline data, either the Student's $t$-test or the Mann-Whitney test were used. The comparison of the variables between groups over time was performed by a $2 \times 4$ or 2x5 factorial ANOVA's. We also tested for ANOVA's assumptions (i.e., data homogeneity and sphericity via Levene and Mauchly tests, respectively). In case of violation of sphericity, the Greenhouse-Geisser correction was applied. The Bonferroni's post-hoc test was utilized to identify the differences; analyses were performed in SPSS (IBM ${ }^{\circledR}$ SPSS $^{\circledR}$ Statistics Inc., Chicago, Illinois, United States), version 24.

\section{RES U L T S}

The participants' age ranged from 18 to 83 years-old ( $M=61.4, S D=15.4)$, with no difference between groups $\left(t_{(1,33)}=0.63, p=0.537\right) .60 \%$ of the sample was comprised by men, albeit no statistically significant difference was present between groups $\left(X^{2}{ }_{(1)}=0.68, p=0.41\right)$. In both groups, haemorrhagic stroke was the main cause of hospitalization (27.8\% in the post-pyloric and $29.5 \%$ in the gastric group). Groups' characteristics at the beginning of the study are presented in Table 1. Lines one to six represent the mean values obtained from days zero to seven. No statistically significant differences were observed between the post-pyloric and gastric groups at baseline. Nonetheless, the prescribed and administered diets, and the number of dietary interruptions, revealed statistically significant variations over the follow-up period (Table 2). Both groups showed increased number of calories prescribed and administered while also demonstrating less diet discontinuations. Increasing reports of diarrhea over time in both groups were present $(p=0.022)$.

The Table 3 contains data on body composition and blood parameters. Among the blood parameters, there was a reduction in haemoglobin $(p=0.011)$ and creatinine $(p=0.007)$, as well as an increase in transferrin $(p=0.003)$ over time and similarly for both groups. However, the group versus time interaction was observed in relation to albumin $(p=0.002)$. Although similar values were observed up to the $21^{\text {st }}$ day, the post-pyloric group showed an increase in albumin levels compared to the gastric group on day 28. While the BMI decreased significantly in both groups over time $(p<0.001)$, there was a trend toward increasing percentages of body fat during the study $(p=0.086)$, possibly indicating nutritional recovery for both groups. 
Table 1 - Group comparisons of investigated variables at baseline. Francisco Beltrão, PR, Brazil, 2019.

\begin{tabular}{|c|c|c|c|}
\hline Variables & Post-pyloric $(n=18)$ & Gastric $(n=17)$ & $p$ value \\
\hline Prescribed diet (kcal/day) & $1275.7 \pm 252.5$ & $1346.2 \pm 296.3$ & $0.453^{*}$ \\
\hline Administered diet (kcal/day) & $1228.3 \pm 254.2$ & $1.73 .5 \pm 295.5$ & $0.630^{*}$ \\
\hline Diet administered according to prescribed (\%) & $96.3 \pm 5.4$ & $94.7 \pm 8.6$ & $0.516^{*}$ \\
\hline Diet interruption $(n)$ & $0.89 \pm 1.13$ & $1.06 \pm 1.25$ & $0.749^{* *}$ \\
\hline Diarrhea record $(n)$ & $1.00 \pm 1.37$ & $0.76 \pm 1.25$ & $0.555^{* *}$ \\
\hline Vomit record (n) & $0.33 \pm 0.84$ & $0.12 \pm 0.33$ & $0.625^{* *}$ \\
\hline Body mass index $\left(\mathrm{kg} / \mathrm{m}^{2}\right)$ & $29.6 \pm 4.2$ & $29.4 \pm 5.6$ & $0.901^{*}$ \\
\hline Relative fat (\%) & $16.0 \pm 9.4$ & $17.3 \pm 10.4$ & $0.701^{*}$ \\
\hline Hemoglobin (g/dL) & $10.3 \pm 2.9$ & $10.8 \pm 2.1$ & $0.614^{*}$ \\
\hline Creatinine $(\mathrm{mg} / \mathrm{dL})$ & $2.01 \pm 1.71$ & $1.97 \pm 1.81$ & $0.958^{*}$ \\
\hline Albumin (g/dL) & $2.90 \pm 0.50$ & $3.10 \pm 0.51$ & $0.250^{*}$ \\
\hline Transferrin (mg/dL) & $132.8 \pm 36.1$ & $129.0 \pm 37.9$ & $0.764^{*}$ \\
\hline
\end{tabular}

Note: "Student $t$ test; ${ }^{* *}$ Mann-Whitney test.

Table 2 - Changes in dietary indicators and complications over the follow-up period in both groups. Francisco Beltrão, PR, Brazil, 2019.

\begin{tabular}{|c|c|c|c|c|c|}
\hline Indicators & Post-pyloric $(n=18)$ & Gastric $(n=17)$ & Comparison & $F$ value & $p$ value \\
\hline \multicolumn{6}{|c|}{ Prescribed diet (kcal/day) } \\
\hline Day 7 & $1275.7 \pm 252.5$ & $1346.2 \pm 296.3$ & Group & 0.196 & 0.661 \\
\hline Day 14 & $1329.4 \pm 272.9$ & $1410.5 \pm 349.3$ & Time & 7.144 & 0.001 \\
\hline Day 21 & $1452.8 \pm 339.1$ & $1557.8 \pm 389.7$ & Interaction & 1.633 & 0.199 \\
\hline Day 28 & $1556.6 \pm 294.4$ & $1456.1 \pm 381.1$ & & & \\
\hline \multicolumn{6}{|c|}{ Administered diet (kcal/day) } \\
\hline Day 7 & $1228.3 \pm 254.2$ & $1273.5 \pm 295.5$ & Group & 0.138 & 0.712 \\
\hline Day 14 & $1282.2 \pm 255.1$ & $1377.7 \pm 352.7$ & Time & 4.139 & $0.015^{*}$ \\
\hline Day 21 & $1372.7 \pm 414.3$ & $1470.7 \pm 429.8$ & Interaction & 1.141 & 0.331 \\
\hline Day 28 & $1485.4 \pm 374.2$ & $1389.3 \pm 437.6$ & & & \\
\hline \multicolumn{6}{|c|}{ Administered prescribed diet (\%) } \\
\hline Day 7 & $96.3 \pm 5.4$ & $94.7 \pm 8.6$ & Group & 0.007 & 0.936 \\
\hline Day 14 & $96.4 \pm 5.1$ & $97.7 \pm 4.8$ & Time & 1.287 & 0.283 \\
\hline Day 21 & $93.2 \pm 11.6$ & $93.5 \pm 8.5$ & Interaction & 0.192 & 0.901 \\
\hline Day 28 & $94.8 \pm 11.8$ & $94.3 \pm 10.8$ & & & \\
\hline \multicolumn{6}{|c|}{ Diet interruption (n) } \\
\hline Day 7 & $0.89 \pm 1.13$ & $1.06 \pm 1.25$ & Group & 0.793 & 0.380 \\
\hline Day 14 & $0.56 \pm 0.86$ & $0.59 \pm 1.12$ & Time & 2.993 & $0.048^{*}$ \\
\hline Day 21 & $0.50 \pm 0.99$ & $0.71 \pm 0.69$ & Interaction & 0.155 & 0.888 \\
\hline Day 28 & $0.22 \pm 0.73$ & $0.53 \pm 0.62$ & & & \\
\hline \multicolumn{6}{|c|}{ Diarrhea record (n) } \\
\hline Day 7 & $1.00 \pm 1.37$ & $0.76 \pm 1.37$ & Group & 0.005 & 0.946 \\
\hline Day 14 & $1.78 \pm 1.31$ & $1.59 \pm 1.28$ & Time & 3.341 & $0.022^{*}$ \\
\hline Day 21 & $1.67 \pm 1.19$ & $1.53 \pm 1.18$ & Interaction & 0.731 & 0.536 \\
\hline Day 28 & $1.22 \pm 1.44$ & $1.71 \pm 1.40$ & & & \\
\hline \multicolumn{6}{|c|}{ Vomit record (n) } \\
\hline Day 7 & $0.33 \pm 0.84$ & $0.12 \pm 0.33$ & Group & 1.989 & 0.168 \\
\hline Day 14 & $0.11 \pm 0.47$ & $0.18 \pm 0.53$ & Time & 0.419 & 0.740 \\
\hline Day 21 & $0.28 \pm 0.67$ & $0.06 \pm 0.24$ & Interaction & 0.551 & 0.649 \\
\hline Day 28 & $0.17 \pm 0.71$ & $0.00 \pm 0.00$ & & & \\
\hline
\end{tabular}

Note: ${ }^{*}$ Significant results $(p<0.05)$. 
Table 3 - Changes in body composition and blood parameters over the 28-day follow-up according to nutritional therapy. Francisco Beltrão, PR, Brazil, 2019.

\begin{tabular}{|c|c|c|c|c|c|}
\hline Variables & Post-pyloric $(n=18)$ & Gastric $(n=17)$ & Comparison & $F$ value & $p$ value \\
\hline \multicolumn{6}{|c|}{ Body mass index $\left(\mathrm{kg} / \mathrm{m}^{2}\right)$} \\
\hline Day 0 & $29.6 \pm 4.2$ & $29.4 \pm 5.6$ & Group & 0.001 & 0.974 \\
\hline Day 7 & $28.8 \pm 4.0$ & $29.3 \pm 5.1$ & Time & 8.067 & $<0.001$ \\
\hline Day 14 & $28.0 \pm 4.4$ & $28.2 \pm 4.3$ & Interaction & 0.339 & 0.851 \\
\hline Day 21 & $27.7 \pm 3.3$ & $27.7 \pm 5.6$ & & & \\
\hline Day 28 & $27.1 \pm 3.4$ & $26.4 \pm 4.4$ & & & \\
\hline \multicolumn{6}{|c|}{ Relative fat (\%) } \\
\hline Day 0 & $16.0 \pm 9.4$ & $17.3 \pm 10.4$ & Group & 0.382 & 0.541 \\
\hline Day 7 & $17.1 \pm 10.5$ & $20.8 \pm 9.6$ & Time & 2.251 & 0.086 \\
\hline Day 14 & $18.2 \pm 11.4$ & $23.7 \pm 12.5$ & Interaction & 0.969 & 0.412 \\
\hline Day 21 & $20.8 \pm 14.0$ & $20.0 \pm 14.0$ & & & \\
\hline Day 28 & $21.2 \pm 13.7$ & $21.6 \pm 11.5$ & & & \\
\hline \multicolumn{6}{|c|}{ Hemoglobin (g/dL) } \\
\hline Day 0 & $10.3 \pm 2.9$ & $10.8 \pm 2.1$ & Group & 0.413 & 0.525 \\
\hline Day 7 & $10.1 \pm 2.7$ & $9.8 \pm 1.3$ & Time & 4.269 & $0.011^{*}$ \\
\hline Day 14 & $9.1 \pm 1.5$ & $9.6 \pm 1.1$ & Interaction & 0.301 & 0.789 \\
\hline Day 21 & $8.8 \pm 1.8$ & $9.1 \pm 0.9$ & & & \\
\hline Day 28 & $9.3 \pm 1.5$ & $9.2 \pm 1.3$ & & & \\
\hline \multicolumn{6}{|c|}{ Creatinine (mg/dL) } \\
\hline Day 0 & $2.01 \pm 1.71$ & $1.97 \pm 1.81$ & Group & 0.162 & 0.690 \\
\hline Day 7 & $1.69 \pm 1.53$ & $1.64 \pm 1.50$ & Time & 6.391 & $0.007^{*}$ \\
\hline Day 14 & $1.44 \pm 1.29$ & $1.12 \pm 0.57$ & Interaction & 0.440 & 0.589 \\
\hline Day 21 & $1.37 \pm 1.19$ & $1.03 \pm 0.39$ & & & \\
\hline Day 28 & $1.28 \pm 1.17$ & $1.30 \pm 0.81$ & & & \\
\hline \multicolumn{6}{|c|}{ Albumin (g/dL) } \\
\hline Day 0 & $2.90 \pm 0.50$ & $3.10 \pm 0.51$ & Group & 0.076 & 0.785 \\
\hline Day 7 & $2.85 \pm 0.25$ & $2.84 \pm 0.38$ & Time & 1.696 & 0.155 \\
\hline Day 14 & $2.84 \pm 0.40$ & $2.98 \pm 0.45$ & Interaction & 4.531 & $0.002^{*}$ \\
\hline Day 21 & $3.06 \pm 0.39$ & $2.99 \pm 0.46$ & & & \\
\hline Day 28 & $3.21 \pm 0.48$ & $2.79 \pm 0.36$ & & & \\
\hline \multicolumn{6}{|c|}{ Transferrin (mg/dL) } \\
\hline Day 0 & $132.8 \pm 36.1$ & $129.0 \pm 37.9$ & Group & 0.858 & 0.361 \\
\hline Day 7 & $141.1 \pm 36.3$ & $133.1 \pm 37.8$ & Time & 5.593 & $0.003^{*}$ \\
\hline Day 14 & $151.1 \pm 39.8$ & $145.4 \pm 31.1$ & Interaction & 0.366 & 0.735 \\
\hline Day 21 & $161.9 \pm 47.1$ & $151.2 \pm 32.5$ & & & \\
\hline Day 28 & $162.0 \pm 43.5$ & $144.0 \pm 35.5$ & & & \\
\hline
\end{tabular}

Note: "Significant results $(p<0.05)$.

A group versus time interaction in relation to albumin $(p=0.002)$ was also observed. Although similar values were observed up to the $21^{\text {st }}$ day, the post-pyloric group showed an increase in albumin levels compared to the gastric group on day 28. Moreover, serum transferrin increased without statistically significant changes between groups throughout the study.

\section{DISCUSSION}

This study's goal was to assess possible differences in nutritional markers and clinical complications associated with ENT administered via two routes [14,21]. Baseline data confirmed that patients were malnourished; indeed, albumin, transferrin, and body fat index were below reference values, thus 
corroborating the malnutrition rates observed in hospitalized patients in Brazil [22,23]. Adequate nutrition is especially important for proper metabolism and robust immune response in hospitalized patients, and ENT is key for those in intensive care [24-26]. As nutritional needs are usually higher in hospitalized individuals, the role of ENT is to provide patients with sufficient protein intake, hydration, and to replenish nutrients that might be compromised in the course of treatment [26]. Moreover, ENT in critically ill patients must envision the reduction of clinical complications, such as vomiting, diarrhea, and prolonged hospitalization [27].

In summary, both groups had their BMI values decreasing from hospital admission to the end of the study. Also, although similar values were observed up to the 21st day, in the group versus time interaction in relation to albumin, the post-pyloric group showed increased values when compared to the gastric group on day 28. These findings could indicate clinical and nutritional improvement in the groups, since high BMI scores at the beginning of the study were due to body edema, which is common in critically ill and malnourished patients. Moreover, considering that the values of body fat percentage increased without statistical significance, it is plausible that patients from both groups had adequate nutritional gains. Indeed, over the follow-up period, the variations of the administered/prescribed diets were above $93 \%$ in both groups. In a prospective observational study with $32 \mathrm{ICU}$ patients in ENT for $\geq 72$ hours, Gonçalvez et al. [28] reported that 21 individuals received $70 \%$ or more calories in relation to what was prescribed to them, with a mean percentage of adequacy of $72.3 \pm 16.3 \%$. Similarly, Lins et al. [29], in a study with 45 individuals, noted that the majority reached both caloric (97.8\%) and protein (64.4\%) goals. Cross-sectional evidence, also with ICU patients, suggested that declining BMI values could buffer good clinical evolution in hospitalized patients [30].

The main gastrointestinal complications presented by critical ICU patients at a reference centre in Pernambuco were diarrhea (33.3\%), vomiting, and regurgitation (15.6\%), and constipation (6.7\%) [29]. In our trial, there was no difference between groups in the occurrence of clinical complications, which is in line with previous randomized clinical trials (RCT) revised by Alkhawaja et al. [14]. However, diarrhea increased in both groups over time. In this respect, it is possible to infer that the route of administration of ENT did not interfere on this outcome. Indeed, enteral feeding intolerance and gastrointestinal symptoms might occur as a result of many factors including the severity of diseases, levels of hyperglycaemia, prescribed diets, medications, renal function, necessity of mechanical ventilation, among others $[18,27]$.

Protein is considered the most important macronutrient for hospitalized patients. It has functions in wound healing, maintenance of immunological functions, and lean mass; still, the individual needs of patients are hardly met with industrialized enteral formulations [31,32]. The amount of protein recommended for hospitalized patients varies according to clinical conditions (metabolic stress, sepsis, acute or chronic renal failure, dialysis, and liver failure). Under these conditions, the recommended protein amounts usually range from 0.8 to $2.0 \mathrm{~g} / \mathrm{kg} /$ day [31,33], albeit more research is needed. In fact, a recent literature review called for further RCT examining optimal protein intake in critically ill patients [34].

Regarding laboratory findings, $88 \%$ of the sample presented albumin values lower than the reference $(M=2.90 \pm 0.67 \mathrm{~g} / \mathrm{dL})$ and the mean transferrin values were $150.31 \pm 54.01 \mathrm{mg} / \mathrm{dL}$, also lower than the reference value [35]. The interaction of time versus group revealed that albumin increased in the postpyloric group. In addition, despite the absence of statistical significance, the post-pyloric group had less diet interruptions over the course of this study, thus effectively receiving more calories. Comparing these results to previous investigations, a systematic review with meta-analysis reported higher nutritional intakes among severely ill patients receiving ENT via post-pyloric route, although caution is necessary when considering albumin as the sole marker of malnutrition or energetic restriction $[8,14]$.

In summary, severe malnutrition in hospitalized patients causes nutrition depletion, reducing glycogen stores and energy reserves, which leads to the body's use of protein mass as an energy source $[36,37]$. Severe 
malnutrition may increase the recovery time and cause general impairment $[5,7]$. With the interruption of ENT, a proper administration of prescribed diet may not occur, leading to malnutrition $[17,36,38,39]$. This, in turn, increases the susceptibility for infections and mortality. Hence, administering ENT in an early, appropriate manner in ICU patients is paramount to reducing morbidity, mortality, and infections. Although this study presents robust and longitudinal information on both nutritional and clinical variables associated with ENT in critical patients, it has some limitations that could be tackled in future studies. For instance, specific differences in nutritional markers and clinical complications according to patients' diagnosis were not examined. Moreover, additional variables, including hydration status and inflammatory conditions, could offer a more in-depth perspective of the benefits associated with one form of ENT administration or the other in critically ill individuals.

\section{CONCLUSION}

There were no differences between the complications inherent to the use of ENT between the two groups. Albumin statistically increased in the post-pyloric group in relation to the gastric group in the last week of the study.

\section{CONTRIBUTORS}

LAK Opsfelder, AP Vieira, LED Ferreto, and MD Massarollo designed the study, performed the data collection, data analysis, and the writing of the article. DRP Silva and GW Wendt contributed to the data analysis and writing of the article.

\section{REFERE N CES}

1. Waitzberg DL, Caiaffa WT, Correia MIT. Hospital malnutrition: the Brazilian national survey (IBRANUTRI): a study of 4000 patients. Nutrition. 2001;17(7-8):573-80. https://doi.org/10.1016/S0899-9007(01)00573-1

2. Sauer AC, Goates S, Malone A, Mogensen KM, Gerwits G, Sulz I, et al. Prevalence of malnutrition risk and the impact of nutrition risk on hospital outcomes: results from nutrition day in the U.S. J Parenter Enteral Nutr. 2019;43(7):918-26. https://doi.org/10.1002/jpen.1499

3. Correia MIT, Perman MI, Waitzberg DL. Hospital malnutrition in Latin America: a systematic review. Clin Nutr. 2017;36(4):958-67. https://doi.org/10.1016/j.clnu.2016.06.025

4. Zhao VM, Ziegler TR, Davis KA. Parenteral nutrition. In: Davis KA, Rosenbaum SH, editors. Surgical metabolism. Switzerland: Springer; 2020 [cited 2020 Aug. 26]; 251-60. Available from: https://www.springer.com/gp/ book/9783030397807

5. Valladares AF, Kilgore KM, Partridge J, Sulo S, Kerr KW, McCauley S. How a malnutrition quality improvement initiative furthers malnutrition measurement and care: results from a hospital learning collaborative. J Parenter Enteral Nutr. 2020; 45(2):367-71. https://doi.org/10.1002/jpen.1833

6. Council of Europe Committee of Ministers. Resolution RESAP (2003)3 on food and nutritional care in hospitals. France; 2003. [cited 2020 Aug. 26]. Available from: https://rm.coe.int/16805de855

7. Kopp Lugli A, Watteville A, Hollinger A, Goetz N, Heidegger C. Medical Nutrition Therapy in Critically III Patients Treated on Intensive and Intermediate Care Units: a literature review. J Clin Med. 2019;8(9):1395. https://doi. org/10.3390/jcm8091395

8. White JV, Guenter P, Jensen G, Malone A, Schofield M, Academy Malnutrition Work Group, et al. Consensus Statement: Academy of Nutrition and Dietetics and American Society for Parenteral and Enteral Nutrition: Characteristics Recommended for the Identification and Documentation of Adult Malnutrition (Undernutrition). J Parenter Enteral Nutr. 2012;36(3):275-83. https://doi.org/10.1177/0148607112440285 
9. Ministério da Saúde (Brasil). Secretaria de Atenção à Saúde, Departamento de Atenção Especializada e Temática. Manual de terapia nutricional na atenção especializada hospitalar no âmbito do Sistema Único de Saúde - SUS. Brasília: Ministério; 2016 [citado 2020 ago. 26]. Disponível em: https://bvsms.saude.gov.br/bvs/publicacoes/ manual_terapia_nutricional_atencao_especializada.pdf

10. Reber E, Gomes F, Vasiloglou MF, Schuetz P, Stanga Z. Nutritional risk screening and assessment. J Clin Med. 2019;8(7):1065. https://doi.org/10.3390/jcm8071065

11. Gubari MIM, Hosseinzadeh-Attar MJ, Hosseini M, Mohialdeen FA, Othman H, Hama-ghareeb KA, et al. Nutritional status in intensive care unit: a meta-analysis and systematic review. Galen Med. 2020;9. https://doi.org/10.31661/ gmj.v9i0.1678

12. van Zanten $A R H$, De Waele E, Wischmeyer PE. Nutrition therapy and critical illness: practical guidance for the ICU, post-ICU, and long-term convalescence phases. Crit Care. 2019;23(1):368. https://doi.org/10.1186/s13054-0192657-5

13. Ministério da Saúde (Brasil). Agência Nacional de Vigilância Sanitária. Resolução da Diretoria Colegiada 63, de 6 de julho de 2000. Aprova o regulamento técnico para fixar os requisitos mínimos exigidos para a terapia de nutrição enteral. Brasília: Ministério; 2000 [citado 2020 ago. 26]. Disponível em: https://www20.anvisa.gov.br/ segurancadopaciente/index. php/legislacao/item/resolucao-da-diretoria-colegiada-rcd-n-63-de-6-de-julho-de-2000

14. Alkhawaja S, Martin C, Butler RJ, Gwadry-Sridhar F. Post-pyloric versus gastric tube feeding for preventing pneumonia and improving nutritional outcomes in critically ill adults. Cochrane Database of Syst Rev. 2015;(8). https://doi. org/10.1002/14651858.CD008875.pub2

15. McClave SA, Taylor BE, Martindale R, et al. Guidelines for the provision and assessment of nutrition support therapy in the adult critically ill patient: Society of Critical Care Medicine (SCCM) and American Society for Parenteral and Enteral Nutrition (ASPEN). J Parenter Enteral Nutr. 2016;40(2):159-211. https://doi.org/10.1177/0148607115621863

16. Singer P, Blaser AR, Berger MM, Alhzzani W, Calder PC, Caeser MP, et al. ESPEN guideline on clinical nutrition in the intensive care unit. Clin Nutr. 2019;38(1):48-79. https://doi.org/10.1016/j.clnu.2018.08.037

17. Salciute-Simene E, Stasiunaitis R, Ambrasas E, Tutkus J, Milkeviius I, Sostakaite G, et al. Impact of enteral nutrition interruptions on underfeeding in intensive care unit. Clin Nutr. 2020;40(3):1310-7. https://doi.org/10.1016/j. clnu.2020.08.014

18. Lewis K, Alqahtani Z, McIntyre L, Almenawer S, Alshami F, Rhodes A, et al. The efficacy and safety of prokinetic agents in critically ill patients receiving enteral nutrition: a systematic review and meta-analysis of randomized trials. Crit Care. 2016;20(1):259. https://doi.org/10.1186/s13054-016-1441-z

19. José IB, Leandro VA, Aquino JLB. Target, prescription and infusion of enteral nutritional therapy of critical patients in intensive care unit. Arq Gastroenterol. 2018;55(3):283-9. https://doi.org/10.1590/s0004-2803.201800000-72

20. Biodynamics. Quick start guide for the BIA 310e. Seattle: Biodynamics Corporation; 2017.

21. McLaren S, Arbuckle C. Providing optimal nursing care for patients undergoing enteral feeding. Nurs Stand. 2020;35(3):60-5. https://doi.org/10.7748/ns.2020.e11520

22. Cendron G, Silva LJ, Closs VE, Schwanke CHA, El Kik RM. Estado Nutricional e Capacidade Funcional em idosos hospitalizados. Rev Graduação. 2016; [citado 2020 ago. 26]9(1):1-6. Disponível em: https://revistaseletronicas.pucrs. br/ojs/index.php/graduacao/article/view/23955

23. Fugolar F, Hacke A, Polakowski CB, Kato M. Relação do índice de risco nutricional com complicações pós-operatórias de cirurgias do sistema digestório em um hospital oncológico. Nutr Clin Diet Hosp. 2016;36(4):34-40. https://doi. org/10.12873/364fugolar

24. Gohel TD, Kirby DF. Access and Complications of Enteral Nutrition Support for Critically III Patients. In: Nutrition Support for the Critically III. Springer; 2016[cited 2020 Aug. 26]:63-9. Available from: https://link.springer.com/ chapter/10.1007/978-3-319-21831-1_5

25. Kampa JCC, Oliveira Reis L, Mezzomo TR, Quadros Camargo C. Pacientes sob terapia nutricional enteral e prevalência de interações fármaco-nutrientes no ambiente hospitalar. Res Soc Dev. 2020;9(3):e162932680-e162932680. https:// doi.org/10.33448/rsd-v9i3.2680

26. Javid Z, Shadnoush M, Khadem-Rezaiyan M, Honarvar NMZ, Sedaghat A, Hashemian SM, et al. Nutritional adequacy in critically ill patients: Result of PNSI study. Clin Nutr. 2020;40(2):511-7. https://doi.org/10.1016/j.clnu.2020.05.047

27. Reintam Blaser A, Deane AM, Preiser J, Arabi YM, Jakob SM. Enteral feeding intolerance: updates in definitions and pathophysiology. Nutr Clin Pract. 2020;36(1):40-9. https://doi.org/10.1002/ncp.10599 
28. Gonçalves CV, Borges LR, Orlandi SP, Bertacco RTA. Monitoramento da terapia nutricional enteral em unidade de terapia intensiva: adequação calórico proteica e sobrevida. Braspen J. 2017[citado 2020 ago 26];32(4):341-6. Disponível em: http://arquivos.braspen.org/journal/jul-ago-set-2019/artigos/12-AdequacaocaEenergia.pdf

29. Lins NF, Dias CA, Oliveira M, Nascimento C, Barbosa JM. Adequação da terapia nutricional enteral em pacientes críticos de um centro de referência em Pernambuco. Rev Bras Nutr Clin. 2015[citado 2020 ago 26];30(1):76-81. Disponível em: http://www.braspen.com.br/home/wp-content/uploads/2016/11/14-Adequa\%C3\%A7\%C3\%A3oda-Terapia-Nutricional.pdf

30. Santos F, Viana K. Avaliação do estado nutricional e da terapêutica dietética de pacientes internados em uma unidade de terapia intensiva. Rev Pesq Saúde. 2016[citado 2020 ago 26];17(1):42-6. Disponível em: http://www. periodicoseletronicos.ufma.br/index.php/revistahuufma/article/view/5502

31. Looijaard W, Denneman N, Broens B, Girbes A, Weijs P, Oudemans-Van Straaten H. Achieving protein targets without energy overfeeding in critically ill patients: a prospective feasibility study. Clin Nutr. 2019;38(6):2623-31. https://doi. org/10.1016/j.clnu.2018.11.012

32. Singer P. Preserving the quality of life: nutrition in the ICU. Crit Care Med. 2019;23(1):139. https://doi.org/10.1186/ s13054-019-2415-8

33. Bendavid I, Zusman O, Kagan I, Theilla M, Cohen J, Singer P. Early administration of protein in critically ill patients: a retrospective cohort study. Nutrients. 2019;11(1):106. https://doi.org/10.3390/nu11010106

34. Arabi YM, Al-Dorzi HM, Sadat M. Protein intake and outcome in critically ill patients. Curr Opin Clin Nutr Metab Care. 2020;23(1):51-8. https://doi.org/10.1097/MCO.0000000000000619

35. Kim S, McClave SA, Martindale RG, Miller KR, Hurt RT. Hypoalbuminemia and clinical outcomes: what is the mechanism behind the relationship? Am Surg. 2017;83(11):1220-7. https://doi.org/10.1177/000313481708301123

36. Rocha AJSC, Oliveira ATV, Cabral NAL, Gomes RS, Guimarães TA, Rodrigues WB, et al. Causas de interrupção de nutrição enteral em unidades de terapia intensiva. Rev Pesq Saúde. 2018[citado 2020 ago 26];18(1):49-53. Disponível em: http://www.periodicoseletronicos.ufma.br/index.php/revistahuufma/article/download/7880/4875

37. Weijs PJM, Mogensen KM, Rawn JD, Christopher KB. Protein intake, nutritional status and outcomes in ICU survivors: a single center cohort study. J Clin Med. 2019;8(1):43. https://doi.org/10.3390/jcm8010043

38. Peev MP, Yeh DD, Quraishi SA, Osler P, Chang Y, Gillis E, et al. Causes and consequences of interrupted enteral nutrition: a prospective observational study in critically ill surgical patients. J Parenter Enteral Nutr. 2015;39(1):21-7. https://doi.org/10.1177/0148607114526887

39. Pinheiro DS, do Santo FHE, Ribeiro WA, Fassarella BPA. Fatores de interrupção de nutrição enteral em unidades de terapia intensiva adulto: revisão integrativa. Res Soc Dev. 2020;9(9):e985998188. https://doi.org/10.33448/rsdv9i9.8188 